\title{
Ammonia-oxidizing microorganisms: key players in the promotion of plant growth
}

\author{
Adenike Eunice Amoo and Olubukola Oluranti Babalola*
}

Food Security and Safety, Faculty of Natural and Agricultural Sciences, North-West University, Private Bag X2046, Mmabatho 2735, South Africa. *Corresponding author: olubukola.babalola@nwu.ac.za

\begin{abstract}
Nitrogen $(\mathrm{N})$ is the most important mineral nutrient required by plants. Although some plants can directly utilize $\mathrm{N}$, ammonium $\left(\mathrm{NH}_{4}^{+}\right)$and nitrate $\left(\mathrm{NO}_{3}^{-}\right)$are the only forms of $\mathrm{N}$ that are usable to most plants. Ammoniaoxidizing bacteria (AOB) and ammonia-oxidizing archaea (AOA) are the key drivers that are responsible for the conversion of $\mathrm{N}$ into usable forms. Due to the importance of ammonia oxidizers (AOs), factors affecting their abundance and activity have been a major research focus over the years. This review focuses on the diversity of AOs, the factors that affect their abundance and activity in different soil types and the mechanism of nitrification. An improved understanding of the combinatorial effects of highly active AOs and methods for limiting nitrate loss from soils may enhance the management of nitrate in soils and improve plant yields.
\end{abstract}

Keywords: Abiotic, ammonia, biotic, diversity, nitrification, nitrogen

\section{Introduction}

Ammonia occurs naturally in the environment and can be found in the soil, where it is an important source of nitrogen for plants. Ammonium does not typically accumulate in soils because it is quickly converted by soil microbes. Ammonia and ammonium are primary energy substrates and are important nitrogen sources for microorganisms in the soil (Daebeler et al., 2014). The oxidation of ammonia or ammonium by organisms is known as nitrification, and microorganisms that are associated with the rhizosphere of plants thrive in the phyllosphere. These organisms live inside the plants as endophytes, on the plant surfaces as epiphytes and in soils surrounding the roots. They can be beneficial, harmful or detrimental to the growth and development of plants. However, it is noteworthy that most of the different plant-colonizing microorganisms follow a commensal lifestyle (Knief, 2014). Soil microorganisms are the greatest contributors to the diversity of terrestrial ecosystems and are the major controllers 
of almost all global biogeochemical cycles. They are essential in the maintenance of plant health through their nutrient cycling roles and relationships with other organisms (Hassan et al., 2015).

Nitrification describes the oxidation of ammonium $\left(\mathrm{NH}_{4}^{+}\right)$or ammonia $\left(\mathrm{NH}_{3}\right)$ to nitrate by living organisms and is a primary activity within the nitrogen $(\mathrm{N})$ cycle. The oxidation of ammonium to nitrate is a twostep process involving the transformation of ammonia or ammonium to nitrite and the conversion of nitrite to nitrate. The first and rate limiting step of nitrification is the oxidation of ammonia to nitrite. It was believed that this process was solely controlled by ammonia-oxidizing bacteria (AOB), which were first isolated in the $19^{\text {th }}$ century (Prosser and Nicol, 2012). The recent discovery of ammonia-oxidizing archaea has challenged this notion (Könneke et al., 2005). In the first step of nitrification, ammonia is converted into hydroxylamine by the enzyme ammonia monooxygenase. Hydroxylamine is then converted to nitrite by the enzyme hydroxylamine oxidoreductase. Nitrite-oxidizing bacteria that produce the enzyme nitrite oxidoreductase aid in the conversion of nitrite to nitrate (Kowalchuk and Stephen, 2001). Leininger et al. (2006) reported that ammonia-oxidizing archaea (AOA) were more abundant than ammonia-oxidizing bacteria in different European soils. This was the first study that revealed the importance of AOA in ammonia oxidation, and various studies have shown the importance of AOA in soil ammonia oxidation in recent years.

The importance of nitrogen to plants cannot be overemphasized. It is the most essential nutrient required by plants as it is a component of nucleic acids, which make up the DNA of all organisms. It is also a component of chlorophyll which is used for photosynthesis. It greatly controls the output of fields, the pattern of growth of plants and their chemical composition (Crawford, 1995, Lobos Ortega et al., 2016, Wu et al., 2016). Not all plants are able to directly use atmospheric nitrogen, and most are only able to use inorganic forms of nitrogen, such as ammonium and nitrate. Although it is only transiently present in the soil, nitrate is a crucial form of nitrogen that can be assimilated by plants (Crawford, 1995). The oxidation of ammonia by microbes is of great importance because ammonia oxidizers are responsible for the production of approximately $10 \mathrm{~kg} \mathrm{~N} /$ ha of nitrate, which is approximately $90 \%$ of the yearly supply of fixed nitrogen (Smith et al., 1998).

The function of ammonia-oxidizing microbes cannot be overstated in soils. This review focuses on the factors affecting the abundance and activity of ammonia-oxidizing microbes and discusses the importance of ammonia-oxidizing microbes in nitrification in different soil types.

\section{Autotrophic nitrification}

Nitrification in the soil is controlled by autotrophic nitrifying microorganisms (archaeal and bacterial ammonia-oxidizers) (Prosser and Nicol, 2012). The oxidation of ammonia/ammonium by autotrophic microorganisms is a two-step process involving the transformation of ammonium by ammonia monooxygenase to hydroxylamine $\left(\mathrm{NH}_{2} \mathrm{OH}\right)$, which is subsequently converted to $\mathrm{NO}_{2}^{-}$by hydroxylamine oxidoreductase (De Boer and Kowalchuk, 2001). Chemolithoautotrophic nitrification is limited to a comparatively narrow group of microorganisms (Head et al., 1993). Ammonia monooxygenase (amo) is the primary enzyme responsible for chemolithoautotrophic nitrification. Ammonia monooxygenase is a membrane-bound enzyme that has three subunits, amoA, amoB and amoC (Sayavedra-Soto et al., 1998). The amoA gene, which is a metabolic hallmark of autotrophic nitrifying microorganisms, has been used as a molecular proxy in environmental microbiology (Stahl and de la Torre, 2012). 


\section{Heterotrophic nitrification}

The occurrence of nitrification in soils with a low $\mathrm{pH}$ has been argued to be indicative of heterotrophic nitrification (Zhang et al., 2015). Nevertheless, De Boer and Kowalchuk (2001) reported that acid-tolerant autotrophic nitrifiers could also play such roles. Both organic and inorganic substrates can be utilized by heterotrophic nitrifiers. The actual indicators of heterotrophic nitrification may have been misunderstood, since some heterotrophic nitrifiers also have denitrifying abilities and accumulate little or no nitrate (Matheson et al., 2003). Stutzer and Hartleb (1896) investigated and gave an account of a fungus that had the ability to produce nitrate. Many additional heterotrophic organisms have been subsequently implicated in the oxidation of different nitrogen compounds in culture (Schimel et al., 1984). Different studies have shown the importance of heterotrophic nitrification. Nitrification by heterotrophs differs strikingly from autotrophic nitrification because it is not associated with cellular growth (Zhang et al., 2015).

\section{Diversity of ammonia oxidizers}

Numerous microorganisms including bacteria, archaea and even fungi have ammonia-oxidizing abilities. AOB are widely distributed in the soil. The conversion of ammonia to nitrite, which is the first and rate-limiting step of nitrification, is controlled by chemolithoautotrophic $\mathrm{AOB}$, and these organisms have the ability to make effective use of this process as their sole energy source (Matsuno et al., 2013). Various bacteria have been reported as ammonia oxidizers, including Nitrosomonas, Nitrosospira (Shen et al., 2012) and Nitrosococcus (Teske et al., 1994). The genera Nitrosomonas and Nitrosospira are members of a monophyletic group in the $\beta$-subdivision of the Proteobacteria (Matsuno et al., 2013). The genus Nitrosococcus belongs to the $\gamma$-subdivision of the Proteobacteria and members of this genus only oxidize ammonia in marine environments (Teske et al., 1994). Paracoccus denitrificans, Pseudomonas putida, Thiosphaera pantotropha and Alcaligenes faecalis are heterotrophic nitrifying bacteria (Crovadore et al., 2015, Van Niel et al., 1992). The presence of the amoA gene in uncultivated species Crenarchaeota was revealed through complementary metagenomic studies of seawater (Venter et al., 2004) and soil (Treusch et al., 2005). Nitrosopumilus maritimus, which was isolated from the rocky substratum of a tropical marine aquarium tank, was the first AOA identified. It is the first identified archaeal chemolithoautotrophic nitrifier and the first mesophile identified in the marine group I Crenarchaeota (Könneke et al., 2005). AOA are members of a novel phylum Thaumarchaeota (Auyeung et al., 2015). They were first identified as members of Crenarchaea (Brochier-Armanet et al., 2008). Other archaeal nitrifiers include Candidatus Nitrosocaldus yellowstonii, Cenarchaeum symbiosum and Candidatus Nitrososphaera gargensis (De la Torre et al., 2008). Nitrification was believed to have only been brought about by bacteria and archaea. However, some fungi including Aspergillus flavus, Penicillium and Absidia cylindrospora, have been implicated in this process (Zhu et al., 2015).

\subsection{Mechanism of ammonia oxidation by ammonia- oxidizing microorganisms}

Nitrification is divided into two processes, nitritation and nitratation. Nitritation is the first step of nitrification and can be divided into three steps: (1) the oxidation of ammonia into hydroxylamine which takes place with the aid of the enzyme ammonia monooxygenase (amo); (2) the reduction of hydroxylamine into nitrite; and (3) the conversion of electrons, free hydrogen ions 
and oxygen into water. Nitritation results in the acidification of the environment.

Nitratation is the second step of nitrification and the enzyme nitrite oxidoreductase, which is produced by nitrite-oxidizing bacteria (NOB), is involved in this process. Nitratation is divided into two steps: (1) the oxidation of nitrite into nitrate by the enzyme nitrite oxidoreductase; and (2) the assemblage of oxygen, protons and electrons into water. When the rate of nitritation is faster than nitratation, nitrite accumulates and leads to proliferation of nitrous oxide. When nitratation is faster, only a small quantity of nitrite is produced (Buday et al., 2000, Philips et al., 2002). (Figure 1)

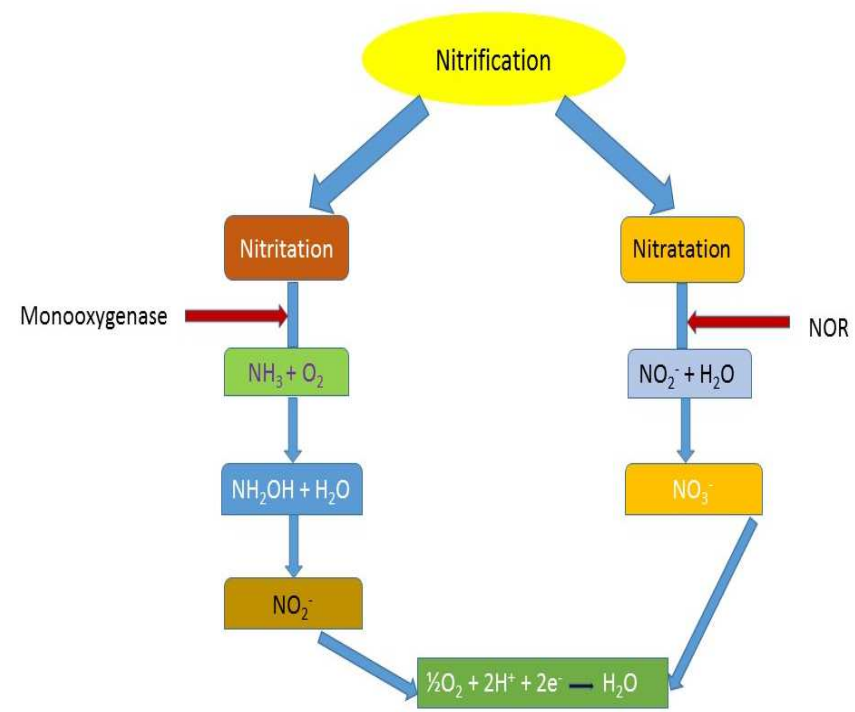

Figure 1. The mechanism of nitrification

\subsection{Function and activity of ammonia-oxidizing mi-}

crobes in different soil types

The diversity of soil microorganisms is extremely large and the structure, growth and activity of the microbial communities in soils can be assessed by biotic and abiotic factors. In different soil systems, the modulation of environmental factors causes changes in the communities of ammonia-oxidizing microbes (Shen et al., 2012).

\subsection{1. $\mathrm{pH}$}

Various factors, such as changes in land use, the deposition of acids and fire, significantly influence the $\mathrm{pH}$ of soils. Microbial communities, and the biogeochemical cycles which they mediate, are significantly affected by soil $\mathrm{pH}$. Fungi thrive more than bacteria in soils with low $\mathrm{pH}$, and the soil $\mathrm{pH}$ greatly influences bacterial diversity and community structure. Past studies have shown that the community structure of 
ammonia-oxidizing microbes is highly influenced by pH (Zhang et al., 2012). Thus, soil pH is an indicator of the relative abundance of the ammonia-oxidizing microorganisms present in soils, the only soil property with the ability to do so (Prosser and Nicol, 2012). The soil $\mathrm{pH}$ is low for approximately $30 \%$ of the total land area in the world, and approximately $54 \%$ of land that is suitable for growing crops in the world has acidic soil (Che et al., 2015). As a result of the low concentrations of nitrate in acid soils $\left(\mathrm{pH}_{\text {water }}<\right.$ 5 ), in the beginning of the $20^{\text {th }}$ century it was believed that nitrification did not occur in such soils (Noyes and Conner, 1919). In the middle of the $20^{\text {th }}$ century, it became known that nitrification could take place in such soils and that low soil $\mathrm{pH}$ does not hinder the activities of nitrifying microorganisms (Robertson, 1982). Nevertheless, in acidified soils, the intensity of nitrification is lower than what is attainable in soils with higher $\mathrm{pH}$ values (Yao et al., 2011). A decrease in the availability of $\mathrm{NH}_{3}$ causes an exponential decrease in the $\mathrm{pH}$ of soil (De Boer and Kowalchuk, 2001). In addition, the fertility of acidic soils is low due to the existence of toxic metals and a shortage of nutrients, possibly influencing soil nitrifying microorganisms (AOB and AOA). Exceptions to this generalization do occur (Yao et al., 2011) which can be ascribed to the fact that acid tolerant nitrifying organisms can be active in both soils with high and low $\mathrm{pH}$ values, while those organisms that are not acid tolerant only function in soils with a higher $\mathrm{pH}$.

Recent studies have shown that AOA are the most active ammonia-oxidizers in acidic soils, even though different mechanisms have been suggested for the activity of AOB in such environments (Zhang et al., 2012). Various studies have quantified the comparative importance of heterotrophic and autotrophic nitrification in forest or pasture soils with low $\mathrm{pH}$. (Table 1)
Several mechanisms by which the $\mathrm{pH}$ of soil affects the activity and growth of functional groups of microbes have been ascertained by a combination of physiological and microcosm studies of soil (Nicol et al., 2008, De Boer and Kowalchuk, 2001).

\subsubsection{Bioavailability of nutrients}

The activities of nitrifying microorganisms can be restricted by the availability of a limited range of substrates and is a significant feature controlling heterotrophic nitrification (Zhang et al., 2014). There are two pathways by which the production of nitrate from ammonia occurs in soil, either through the action of chemoautotrophic nitrifiers or by heterotrophic nitrification, which is controlled by heterotrophic nitrifying bacteria or fungi (Zhang et al., 2013a, Zhang et al., 2013b). Depending on the availability of substrates in the soil, fungal nitrifiers have the ability to switch to other nitrification pathways (Aarnio and Martikainen, 1992). The contribution of heterotrophic nitrification can be determined by the $\mathrm{C} / \mathrm{N}$ ratio of the $\mathrm{N}$ substrate. The possession of a high $\mathrm{C} / \mathrm{N}$ ratio by organic $\mathrm{N}$ compounds, which intensifies the bioavailability of $\mathrm{C}$, can stimulate the growth of heterotrophic bacteria, thereby resulting in the inhibition and displacement of nitrifying bacterial growth and the activity of autotrophic nitrifiers. Inhibition of microbial competition is a possible consequence of the production of by-products by fungal nitrifiers. Inorganic and organic substrates can be effectively used as sources of nitrification. Nitrogen compounds from different sources can function as substrates for heterotrophic nitrification. Organic nitrogen compounds have been utilized as substrates for heterotrophic nitrification in acidic soils (Zhang et al., 2014). 
Table 1. Effect of $\mathrm{pH}$ on the nitrifying microbial population in different soil types

\begin{tabular}{|c|c|c|c|c|}
\hline Sampling site & Soil type & $\mathrm{pH}$ range & Observations & References \\
\hline $\begin{array}{l}\text { Wanmulin Nature Reserve, Fujian } \\
\text { province (China) }\end{array}$ & Red soils & $3.9-5.2$ & $\begin{array}{l}\text { The } \mathrm{pH} \text { of the soils had no significant effect on the heterotrophic } \\
\text { nitrifiers }\end{array}$ & (Zhang et al., 2014) \\
\hline $\begin{array}{l}\text { Shuangzhen Forestry Centre, Jiangxi } \\
\text { Province (China) }\end{array}$ & $\begin{array}{l}\text { Subtropical } \\
\text { coniferous forest soil }\end{array}$ & 4.5 & $\begin{array}{l}\text { The heterotrophic nitrifiers, to a great extent, controlled } \mathrm{NO}_{3}{ }^{-} \\
\text {production, while the autotrophic nitrifiers had a negligible } \\
\text { impact }\end{array}$ & (Zhu et al., 2015) \\
\hline $\begin{array}{l}\text { Lake Duparquet Research and Teaching } \\
\text { Forest (northwestern Quebec, Canada) }\end{array}$ & Grey luvisols & $-2-2$ & $\begin{array}{l}\text { The link between } \mathrm{pH} \text { and net nitrification was exceedlingly } \\
\text { strong. The optimal } \mathrm{pH} \text { values for all nitrifying organisms, except } \\
\text { for two, were higher than } 5.3\end{array}$ & (Ste-Marie and Paré, 1999) \\
\hline Farmlands (China) & Dry soils & $4.85-7.62$ & $\begin{array}{l}\text { Archaeal amoA genes were more functional than bacterial amoA } \\
\text { genes in most of the study sites. There was significant positive } \\
\text { correlation between the AOA amoA genes and } \mathrm{pH} \text {. }\end{array}$ & (Baolan et al., 2014) \\
\hline $\begin{array}{l}\text { C. Hart Merriam Elevation Gradient } \\
\text { (northern Arizona, USA) }\end{array}$ & & $6.0-7.8$ & $\begin{array}{l}\text { The archaeal amoA genes, which were present in greater quantity } \\
\text { compared to the bacterial amoA genes, were not significantly }\end{array}$ & (Adair and Schwartz, 2008) \\
\hline Great Basin & $\begin{array}{l}\text { Pachic Udic } \\
\text { Argiboroll }\end{array}$ & & $\begin{array}{l}\text { related to all the environmental variables considered in all the } \\
\text { soils studied. }\end{array}$ & \\
\hline Grassland & Mollic Eutroboralf & & & \\
\hline Pinyon-Juniper & Calcic Haplustand & & & \\
\hline Ponderosa & Typic Haplustoll & & & \\
\hline Mixed Conifer & Lithic Camborthid & & & \\
\hline Meadow in Fureneset (western Norway) & Sapric histosol & $4.1-7.9$ & Unexpectedly, the $\mathrm{pH}$ had no effect on the rates of nitrification. & (Mørkved et al., 2007) \\
\hline $\begin{array}{l}\text { Permanent wheat field (southeast } \\
\text { Norway) }\end{array}$ & Stagnic Albeluvisol & $5.0-6.1$ & & \\
\hline Meadow in Öjebyn (northern Sweden) & Mineral soil & $5.2-7.2$ & & \\
\hline
\end{tabular}

Substrates in the soil are determinants of the vegetation that can be found in a particular area. The N-resorption efficiency of various types of vegetation is different and because of this, different plant groups have different concentrations of $\mathrm{N}$ and different $\mathrm{C} / \mathrm{N}$ ratios. The plant population in a given locality influences the activities of microorganisms present in the soil and the cycling of nutrients (Bosco et al., 2015, Rumpel et al., 2015). The influence and availability of substrates on nitrification have been argued to be more important than $\mathrm{pH}$. The addition of substrates in different treatments can cause noteworthy changes in the soil $\mathrm{pH}$. For example, Zhang et al. (2014) reported significant changes in the $\mathrm{pH}$ of soil after the addition of substrates. Low concentrations of ammonium may curtail the growth of AOA or cause the $\mathrm{N}$ concentration of ecosystems to be low (Könneke et al., 2005). The demand for $\mathrm{NH}_{3}$ for microbial growth differs between AOA and AOB. The abundance of AOB declines with soil depth, while
AOA shows little variation (Leininger et al., 2006). $\mathrm{AOB}$ growth is believed to be supported when soil conditions are fertile, whereas AOA have a preference for oligotrophic environments or those with low fertility (Erguder et al., 2009). AOB thrive under conditions of high $\mathrm{NH}_{3}$ availability, whereas AOA prefer low $\mathrm{NH}_{3}$ conditions (Di et al., 2010). The response of nitrification to the availability of $\mathrm{NH}_{4}^{+}$availability can be ascertained by Michaelis-Menten kinetics, and this model has been used to characterize some nitrifiers in soil (Stark and Firestone, 1996).

\subsubsection{Temperature}

Soil microorganisms are highly responsive to high temperatures. Microbial activity generally increases with increasing temperature over the typical ambient temperature range (Gilliam et al., 2015). The sensitivity of soil organic matter mineralization to temperature is 
affected by the type and availability of the substrate (von Lützow and Kögel-Knabner, 2009). Soil temperature can impact the quantity of nitrogen that is present in the soil for plant use and determines the fate of this nitrogen (Thangarajan et al., 2015). Temperature is a determinant of how biological processes that are involved in the transformation of nitrogen in soils function. Similar to all other microorganisms, nitrifiers respond to changes in temperature, and the rate of nitrification in the soil is greatly influenced by temperature. At soil temperatures lower than $10^{\circ} \mathrm{C}$, the occurrence of ammonification instead of nitrification is greater (Emmer and Tietema, 1990). Due to the impact of different microbial communities on nitrification, the impact of temperature on the different soil horizons could be dissimilar (Schütt et al., 2014).

The Arrhenius equation or the $Q_{10}$ function can describe the rate of nitrogen mineralization in response to temperature (Kladivko and Keeney, 1987). The response of nitrification to temperature is correlated with climatic zones (Malhi and McGill, 1982). The climatic conditions in warmer regions support nitrification with an optimum temperature of $35^{\circ} \mathrm{C}$, and the process still takes place at temperatures as high as $50{ }^{\circ} \mathrm{C}$ (Myers, 1975). Global patterns of the storage of soil nitrogen and the stability of soil organic matter may not be the only determining factors of how the mineralization of soil nitrogen responds to climatic change. The link between the recalcitrance of organic matter and the temperature response function could also be a factor (Post et al., 1985). Dalias et al. (2002) investigated the variation between soils in response to temperature of the net mineralization of nitrogen and nitrification. They reported that the regional climate determines the relationship between temperature and the oxidation of ammonia. Thangarajan et al. (2015) studied the influence of temperature on the transformation of nitrogen between organic and inorganic nitrogen sources. They reported that $24{ }^{\circ} \mathrm{C}$ is the optimum temperature in all the soils studied except one. Their study demonstrated a link between the optimum temperature for nitrification and environmental conditions. Additionally, microcosm experiments by Tourna et al. (2008) demonstrated that the community structure of archaeal ammonia oxidizers heightened as the incubation temperatures increased. In high-latitude and altitude ecosystems, the processes of the cold season significantly contribute to the annual mineralization of nitrogen in the soil (Schütt et al., 2014). Although autotrophic nitrifying bacteria do not thrive at cold temperatures (Cookson et al., 2002), the microbial activity in the soil can give a satisfactory record of net nitrogen mineralization (30-50\%) throughout the year since microorganisms remain physiologically active in unfrozen water films (Kielland et al., 2006). Using microbiological and molecular methods, Schadt et al. (2003) reported that the peak tundra soil microbial biomass occurs when it is under snow. Anabolism and catabolism have been shown to persist between -4 and $+9{ }^{\circ} \mathrm{C}$, and these processes may lead to an expansion of microbial nitrogen demand particularly in boreal soils (Drotz et al., 2010). At temperatures below $5{ }^{\circ} \mathrm{C}$, the intensity of the activity of microorganisms in temperate soils may diminish (Pietikäinen et al., 2005). However, Schütt et al. (2014) reported the observation of gross nitrification at low temperatures $\left(-4-8{ }^{\circ} \mathrm{C}\right)$, suggesting that nitrifying microorganisms are functional at such temperatures.

The optimum temperature for the nitrification activity of ammonia oxidizers has been reported by different studies, ranging from $20-37{ }^{\circ} \mathrm{C}$ (Stark, 1996). Justice and Smith (1962) reported that the rate of nitrification at $25{ }^{\circ} \mathrm{C}$ was higher than at $35^{\circ} \mathrm{C}$.

\subsubsection{Soil water content}

In many environments, the activity of microorganisms can be limited by moisture, since a reduction of enzyme activity occurs in many microbes when the 
accessibility of water is low (Stark and Firestone, 1995). Moisture is an important environmental factor that influences nitrogen mineralization in the soil through its effect on the accessibility of substrates to nitrifiers, impacting their physiology and metabolism (Norton and Stark, 2011, Marcos et al., 2016). The rates of net nitrification become elevated as the soil water content increases. However, excess water in soils also leads to oxygen limitation, which reduces the rate of nitrification (Norton and Stark, 2011). When the soil is dry, the water films present in the soil pores become thin, inhibiting the movement of substrates to nitrifiers (Stark and Firestone, 1995). The relationship between moisture and nitrate production in the soil is strong and positive because, although nitrification is an aerobic process, microbial metabolism and the diffusion of substrates is enhanced by soil moisture (Osborne et al., 2016).

Ammonia oxidizers are adversely affected by limited soil water in a number of ways. For example, microbial cells are restricted in the amount of available ammonia; the growth and metabolism of the microbial cells are adversely impacted due to the increased solute concentrations; and the microbial activity becomes low because the intracellular water potential is also lowered (Hu et al., 2015). Several studies have shown an increase in the abundance of the amoA gene in response to soil water (Marcos et al., 2016, Di et al., 2014).

\section{Conclusions}

Ammonia is ubiquitous in nature and is a substrate used to produce nitrate. Ammonia-oxidizing bacteria and archaea are the primary players that participate in the conversion of ammonia to nitrates. Nitrate is the only form of nitrogen which can be utilized by most plants. Some factors, such as $\mathrm{pH}$, availability of substrate, temperature, and moisture content, can hinder activity and determine the abundance of ammonia oxidizers. To obtain optimal plant yields and growth, these factors should be considered and optimized. Much remains to be discovered with regards to ammonia oxidizers. Cultivating different effective ammonia-oxidizers and the use of a consortium of such microbes to increase nitrate production is an area of research that should be actively studied. More effective ways to reduce the loss of nitrate from the soil should also be investigated.

\section{Acknowledgements}

AEA would like to thank the North-West University for postgraduate bursary. This work is based on the research supported by the National Research Foundation of South Africa (Grants Ref: UID81192, UID105248, UID95111; OOB).

\section{References}

Aarnio, T., Martikainen, P. 1992. Nitrification in forest soil after refertilization with urea or urea and dicyandiamide. Soil Biology and Biochemistry. 24, 951-954.

Adair, K.L., Schwartz, E. 2008. Evidence that ammonia-oxidizing archaea are more abundant than ammonia-oxidizing bacteria in semiarid soils of northern Arizona, USA. Microbial Ecology. 56, 420-426.

Auyeung, D., Martiny, J.B., Dukes, J.S. 2015. Nitrification kinetics and ammonia-oxidizing community respond to warming and altered precipitation. Ecosphere. 6, 1-17.

Baolan, H., Shuai, L., Wei, W., Lidong, S., Liping, L., Weiping, L., Guangming, T., Xiangyang, X., Ping, Z. 2014. Ph-dominated niche segregation of ammonia-oxidising microorganisms in Chinese agricultural soils. FEMS Microbiology Ecology. 90, 290-299. 
Bosco, T., Bertiller, M.B., Carrera, A.L. 2015. Micro-environmental conditions affect grass and shrub seedling emergence in denuded areas of the arid Patagonian Monte, Argentina. FloraMorphology, Distribution, Functional Ecology of Plants. 210, 66-71.

Brochier-Armanet, C., Boussau, B., Gribaldo, S., Forterre, P. 2008. Mesophilic Crenarchaeota: proposal for a third archaeal phylum, the Thaumarchaeota. Nature Reviews Microbiology. 6, 245-252.

Buday, J., Drtil, M., Hutnan, M., Derco, J. 2000. Substrate and product inhibition of nitrification. Chem. Papers. 53, 379-383.

Che, J., Zhao, X.Q., Zhou, X., Jia, Z.J. \& Shen, R.F. 2015. High ph-enhanced soil nitrification was associated with ammonia-oxidizing bacteria rather than archaea in acidic soils. Applied Soil Ecology. 85, 21-29.

Cookson, W., Cornforth, I., Rowarth, J. 2002. Winter soil temperature $\left(2-15^{\circ} \mathrm{C}\right)$ effects on nitrogen transformations in clover green manure amended or unamended soils; a laboratory and field study. Soil Biology and Biochemistry. 34, 1401-1415.

Crawford, N.M. 1995. Nitrate: nutrient and signal for plant growth. The Plant Cell. 7, 859.

Crovadore, J., Calmin, G., Cochard, B., Chablais, R., Grizard, D., Berthon, J.Y., Lefort, F. 2015. Whole-genome sequence of Pseudomonas putida strain UASWS0946, a highly ammonia-tolerant nitrifying bacterium isolated from sewage sludge aerobic granules. Genome Announcements. 3, e01153-15.

Daebeler, A., Bodelier, P.L., Yan, Z., Hefting, M.M., Jia, Z., Laanbroek, H.J. 2014. Interactions between Thaumarchaea, Nitrospira and methanotrophs modulate autotrophic nitrification in volcanic grassland soil. The ISME Journal. 8, 2397-2410.
Dalias, P., Anderson, J.M., Bottner, P., Coûteaux, M.M. 2002. Temperature responses of net nitrogen mineralization and nitrification in conifer forest soils incubated under standard laboratory conditions. Soil Biology and Biochemistry. 34, 691-701.

De Boer, W., Kowalchuk, G. 2001. Nitrification in acid soils: micro-organisms and mechanisms. Soil Biology and Biochemistry. 33, 853-866.

De La Torre, J.R., Walker, C.B., Ingalls, A.E., Könneke, M., Stahl, D.A. 2008. Cultivation of a thermophilic ammonia oxidizing archaeon synthesizing crenarchaeol. Environmental Microbiology. 10, 810-818.

Di, H.J., Cameron, K.C., Podolyan, A., Robinson, A. 2014. Effect of soil moisture status and a nitrification inhibitor, dicyandiamide, on ammonia oxidizer and denitrifier growth and nitrous oxide emissions in a grassland soil. Soil Biology and Biochemistry. 73, 59-68.

Di, H.J., Cameron, K.C., Shen, J.P., Winefield, C.S., O'Callaghan, M., Bowatte, S., He, J.Z. 2010. Ammonia-oxidizing bacteria and archaea grow under contrasting soil nitrogen conditions. FEMS Microbiology Ecology. 72, 386-394.

Drotz, S.H., Sparrman, T., Nilsson, M.B., Schleucher, J., Öquist, M.G. 2010. Both catabolic and anabolic heterotrophic microbial activity proceed in frozen soils. Proceedings of the National Academy of Sciences. 107, 21046-21051.

Emmer, I., Tietema, A. 1990. Temperature-dependent nitrogen transformations in acid oak-beech forest litter in the Netherlands. Plant and Soil. 122, 193-196.

Erguder, T.H., Boon, N., Wittebolle, L., Marzorati, M., Verstraete, W. 2009. Environmental factors shaping the ecological niches of ammonia-oxidizing archaea. FEMS Microbiology Reviews. 33, 855-869. 
Gilliam, F.S., Galloway, J.E., Sarmiento, J.S. 2015. Variation with slope aspect in effects of temperature on nitrogen mineralization and nitrification in mineral soil of mixed hardwood forests. Canadian Journal of Forest Research. 45, 958-962.

Hassan, W., Hussain, M., Bashir, S., Shah, A., Bano, R., David, J. 2015. ACC-deaminase and/or nitrogen fixing rhizobacteria and growth of wheat (Triticum Aestivum L.). Journal of Soil Science and Plant Nutrition. 15, 232-248.

Head, I.M., Hiorns, W.D., Embley, T.M., Mccarthy, A.J., Saunders, J.R. 1993. The phylogeny of autotrophic ammonia-oxidizing bacteria as determined by analysis of $16 \mathrm{~S}$ ribosomal RNA gene sequences. Microbiology. 139, 1147-1153.

Hu, H.W., Macdonald, C.A., Trivedi, P., Holmes, B., Bodrossy, L., He, J.Z., Singh, B.K. 2015. Water addition regulates the metabolic activity of ammonia oxidizers responding to environmental perturbations in dry subhumid ecosystems. Environmental microbiology. 17, 444-461.

Justice, J.K., Smith, R. 1962. Nitrification of ammonium sulfate in a calcareous soil as influenced by combinations of moisture, temperature, and levels of added nitrogen. Soil Science Society of America Journal. 26, 246-250.

Kielland, K., Olson, K., Ruess, R.W., Boone, R.D. 2006. Contribution of winter processes to soil nitrogen flux in taiga forest ecosystems. Biogeochemistry. 81, 349-360.

Kladivko, E.J., Keeney, D.R. 1987. Soil nitrogen mineralization as affected by water and temperature interactions. Biology and Fertility of Soils. $5,248-252$.

Knief, C. 2014. Analysis of plant microbe interactions in the era of next generation sequencing technologies. Frontiers in Plant Science. 5, 216.
Könneke, M., Bernhard, A.E., José, R., Walker, C.B., Waterbury, J.B., Stahl, D.A. 2005. Isolation of an autotrophic ammonia-oxidizing marine archaeon. Nature. 437, 543-546.

Kowalchuk, G.A., Stephen, J.R. 2001. Ammonia-oxidizing bacteria: a model for molecular microbial ecology. Annual Reviews in Microbiology. 55, 485-529.

Leininger, S., Urich, T., Schloter, M., Schwark, L., Qi, J., Nicol, G., Prosser, J., Schuster, S., Schleper, C. 2006. Archaea predominate among ammonia-oxidizing prokaryotes in soils. Nature. 442, 806-809.

Lobos Ortega, I., Alfaro, M., Martinez-Lagos, J. 2016. Soil nitrogen contribution to grasslands and its implication for nitrogen use efficiency. Journal of Soil Science and Plant Nutrition. 16, 310-322.

Malhi, S., Mcgill, W. 1982. Nitrification in three Alberta soils: effect of temperature, moisture and substrate concentration. Soil Biology and Biochemistry. 14, 393-399.

Marcos, M.S., Bertiller, M.B., Cisneros, H.S., Olivera, N.L. 2016. Nitrification and ammonia-oxidizing bacteria shift in response to soil moisture and plant litter quality in arid soils from the Patagonian Monte. Pedobiologia. 59, 1-10.

Matheson, F., Nguyen, M., Cooper, A., Burt, T. 2003. Short-term nitrogen transformation rates in riparian wetland soil determined with nitrogen-15. Biology and Fertility of Soils. 38, 129-136.

Matsuno, T., Horii, S., Sato, T., Matsumiya, Y., Kubo, M. 2013. Analysis of nitrification in agricultural soil and improvement of nitrogen circulation with autotrophic ammonia-oxidizing bacteria. Applied Biochemistry and Biotechnology. 169, 795-809.

Mørkved, P.T., Dörsch, P., Bakken, L.R. 2007. The $\mathrm{N}_{2} \mathrm{O}$ product ratio of nitrification and its dependence on long-term changes in soil ph. Soil Biology and Biochemistry, 39, 2048-2057. 
Myers, R. 1975. Temperature effects on ammonification and nitrification in a tropical soil. Soil Biology and Biochemistry. 7, 83-86.

Nicol, G.W., Leininger, S., Schleper, C., Prosser, J.I. 2008. The influence of soil $\mathrm{pH}$ on the diversity, abundance and transcriptional activity of ammonia oxidizing archaea and bacteria. Environmental microbiology. 10, 2966-2978.

Norton, J.M., Stark, J.M. 2011. Regulation and measurement of nitrification in terrestrial systems. Methods in Enzymology. 486, 343-368.

Noyes, H., Conner, S. 1919. Nitrates, nitrification, and bacterial contents of five typical acid soils as affected by lime, fertilizer, crops and moisture. Journal of Agricultural Research. 16, 27-60.

Osborne, B.B., Baron, J.S., Wallenstein, M.D. 2016. Moisture and temperature controls on nitrification differ among ammonia oxidizer communities from three alpine soil habitats. Frontiers of Earth Science. 10, 1-12.

Philips, S., Wyffels, S., Sprengers, R., Verstraete, W. 2002. Oxygen-limited autotrophic nitrification/denitrification by ammonia oxidisers enables upward motion towards more favourable conditions. Applied Microbiology and Biotechnology. 59, 557-566.

Pietikäinen, J., Pettersson, M., Bååth, E. 2005. Comparison of temperature effects on soil respiration and bacterial and fungal growth rates. FEMS Microbiology Ecology. 52, 49-58.

Post, W.M., Pastor, J., Zinke, P.J., Stangenberger, A.G. 1985. Global patterns of soil nitrogen storage. Nature. 317, 613-616.

Prosser, J.I., Nicol, G.W. 2012. Archaeal and bacterial ammonia-oxidisers in soil: the quest for niche specialisation and differentiation. Trends in Microbiology. 20, 523-531.

Robertson, G. 1982. Nitrification in forested ecosystems. Philosophical Transactions of the Royal Society of London B: Biological Sciences. 296, 445-457.
Rumpel, C., Crème, A., Ngo, P., Velásquez, G., Mora, M., Chabbi, A. 2015. The impact of grassland management on biogeochemical cycles involving carbon, nitrogen and phosphorus. Journal of Soil Science and Plant Nutrition. 15, 353-371.

Sayavedra-Soto, L., Hommes, N., Alzerreca, J., Arp, D., Norton, J.M., Klotz, M. 1998. Transcription of the amoc, amoa and amob genes in Nitrosomonas europaea and Nitrosospira sp. Npav. FEMS Microbiology Letters. 167, 81-88.

Schadt, C.W., Martin, A.P., Lipson, D.A., Schmidt, S.K. 2003. Seasonal dynamics of previously unknown fungal lineages in tundra soils. Science. 301, 1359-1361.

Schimel, J.P., Firestone, M.K., Killham, K.S. 1984. Identification of heterotrophic nitrification in a Sierran forest soil. Applied and Environmental Microbiology. 48, 802-806.

Schütt, M., Borken, W., Spott, O., Stange, C.F., Matzner, E. 2014. Temperature sensitivity of C and $\mathrm{N}$ mineralization in temperate forest soils at low temperatures. Soil Biology and Biochemistry. $69,320-327$.

Shen, J.P., Zhang, L.M., Di, H.J., He, J.Z. 2012. A review of ammonia-oxidizing bacteria and archaea in Chinese soils. Frontiers in Microbiology. 3, 1-7.

Smith, R.L., Smith, T.M., Thomas, M.S. 1998. Elements of Ecology.

Stahl, D.A., De La Torre, J.R. 2012. Physiology and diversity of ammonia-oxidizing archaea. Annual Review of Microbiology. 66, 83-101.

Stark, J.M. 1996. Modeling the temperature response of nitrification. Biogeochemistry. 35, 433-445.

Stark, J.M., Firestone, M.K. 1995. Mechanisms for soil moisture effects on activity of nitrifying bacteria. Applied and environmental microbiology. 61, 218-221. 
Stark, J.M., Firestone, M.K. 1996. Kinetic characteristics of ammonium-oxidizer communities in a California oak woodland-annual grassland. Soil Biology and Biochemistry. 28, 1307-1317.

Ste-Marie, C., Paré, D. 1999. Soil, ph and N availability effects on net nitrification in the forest floors of a range of boreal forest stands. Soil Biology and Biochemistry. 31, 1579-1589.

Stutzer, A. \& Hartleb, R. 1896. Ueber nitratbildung. Zen-tralbl. Bakteriol. Parasitenkd. Infektionskr. Hyg. Abt. 2, 701.

Teske, A., Alm, E., Regan, J., Toze, S., Rittmann, B., Stahl, D. 1994. Evolutionary relationships among ammonia-and nitrite-oxidizing bacteria. Journal of Bacteriology. 176, 6623-6630.

Thangarajan, R., Bolan, N.S., Naidu, R., Surapaneni, A. 2015. Effects of temperature and amendments on nitrogen mineralization in selected Australian soils. Environmental Science and Pollution Research. 22, 8843-8854.

Tourna, M., Freitag, T.E., Nicol, G.W., Prosser, J.I. 2008. Growth, activity and temperature responses of ammonia-oxidizing archaea and bacteria in soil microcosms. Environmental Microbiology. 10, 1357-1364.

Treusch, A.H., Leininger, S., Kletzin, A., Schuster, S.C., Klenk, H.P., Schleper, C. 2005. Novel genes for nitrite reductase and Amo-related proteins indicate a role of uncultivated mesophilic crenarchaeota in nitrogen cycling. Environmental Microbiology. 7, 1985-1995.

Van Niel, E., Braber, K., Robertson, L., Kuenen, J. 1992. Heterotrophic nitrification and aerobic denitrification in Alcaligenes faecalis strain TUD. Antonie van Leeuwenhoek. 62, 231-237.
Venter, J.C., Remington, K., Heidelberg, J.F., Halpern, A.L., Rusch, D., Eisen, J.A., Wu, D., Paulsen, I., Nelson, K.E., Nelson, W. 2004. Environmental genome shotgun sequencing of the Sargasso Sea. Science. 304, 66-74.

Von Lützow, M., Kögel-Knabner, I. 2009. Temperature sensitivity of soil organic matter decomposition - what do we know?. Biology and Fertility of Soils. 46, 1-15.

Wu, Q., Xia, G., Chen, T., Wang, X., Chi, D., Sun, D. 2016. Nitrogen use and rice yield formation response to zeolite and nitrogen coupling effects: Enhancement in nitrogen use efficiency. Journal of Soil Science and Plant Nutrition. 16, 999-1009.

Yao, H., Campbell, C.D., Qiao, X. 2011. Soil pH controls nitrification and carbon substrate utilization more than urea or charcoal in some highly acidic soils. Biology and Fertility of Soils. 47, 515-522.

Zhang, J.B., Cai, Z.C., Zhu, T.B., Yang, W.Y., Müller, C. 2013a. Mechanisms for the retention of inorganic $\mathrm{N}$ in acidic forest soils of southern China. Scientific Reports. 3, 1-8.

Zhang, J., Müller, C., Cai, Z. 2015. Heterotrophic nitrification of organic $\mathrm{N}$ and its contribution to nitrous oxide emissions in soils. Soil Biology and Biochemistry. 84, 199-209.

Zhang, J., Sun, W., Zhong, W., Cai, Z. 2014. The substrate is an important factor in controlling the significance of heterotrophic nitrification in acidic forest soils. Soil Biology and Biochemistry. 76, 143-148.

Zhang, L.M., Hu, H.W., Shen, J.P., He, J.Z. 2012. Ammonia-oxidizing archaea have more important role than ammonia-oxidizing bacteria in ammonia oxidation of strongly acidic soils. The ISME Journal. 6, 1032-1045. 
Zhang, Y., Zhang, J., Meng, T., Zhu, T., Müller, C., Cai, Z. 2013b. Heterotrophic nitrification is the predominant $\mathrm{NO}_{3}-$ production pathway in acid coniferous forest soil in subtropical China. Biology and Fertility of Soils. 49, 955-957.
Zhu, T., Meng, T., Zhang, J., Zhong, W., Müller, C., Cai, Z. 2015. Fungi-dominant heterotrophic nitrification in a subtropical forest soil of China. Journal of Soils and Sediments. 15, 705-709. 